\title{
Aptian-Late Cenomanian Fluvio-Lacustrine Lithofacies and Palynomorphs from Mamfe Basin, Southwest Cameroon, West Africa
}

\author{
Olivier A. Njoh ${ }^{1}$, Miriam B. Nforsi ${ }^{1}$, Junie N. Datcheu ${ }^{2}$ \\ ${ }^{1}$ Faculty of Science, Department of Geology, University of Buea, Buea,Cameroon \\ ${ }^{2}$ Faculté des Sciences, Department des Sciences de la Terre, Université de Douala, Douala, Cameroon \\ Email: ${ }^{*}$ joh68@yahoo.fr, florami2@yahoo.com, juniedatcheu@yahoo.fr
}

Received 5 June 2015; accepted 26 July 2015; published 30 July 2015

Copyright (C) 2015 by author and Scientific Research Publishing Inc.

This work is licensed under the Creative Commons Attribution International License (CC BY). http://creativecommons.org/licenses/by/4.0/

\section{Open Access}

\section{Abstract}

The sedimentary sequences in the Mamfe Basin are generally thought of as continental (fluviolacustrine) in origin. But the wide spread occurrence of salt springs and salt accumulations and in places gypsum, often puts to question the exclusive continentality throughout this basin's history. The sequences studied portray a wide range of complex lithologies and lithofacies relationships and include basal and intra-formational conglomerates, sandstones, shales, carbonaceous, carbonate and halite facies respectively. All these are well exposed at several outcrop sections distributed all over the basin with some measuring up to and above $30 \mathrm{~m}$ in height. Sedimentary structures include: parallel aligned imbricated prismatic pebbles, plannar to trough-cross stratifications, fining upward grain size distribution and thin frequently alternating sandstone-shale beds. Palynological data have been obtained for the first time from the shally and carbonate intervals and integrated with five lithofacies associations, permitting the determination of the ages and paleo environmental reconstruction. The palynomorphs are characterized by pteridophytic spores dominated by Cicatricosisporites sp., Cyathidites sp. and Deltoidspora sp., pollen grains include gymnosperms dominated by Classopollis annulatus and Classopollis todosus and angiosperms represented by Retitricolpites sp. and Retimoncolpites sp., fungal remains include some hyphae and Fusiformisporites sp. Only a few dinoflagellate cysts dominantly Spiniferites were encountered at Nfaitok outcrop, suggesting a proximal sea water influence. A fluvial, lacustrine-deltaic and an anoxic deep bottom lake setting sub-environments were reconstructed with no marine strata encountered. The brines are here suggested to have originated from sea water splay over a barrier and complimented by the chemistry of the drained surrounding country rocks. The palynomorph assemblage suggests an Aptian-Turonian age for the studied sequences and a chronostratigraphic sequence in which the Nfaitok and Satom Bridge units are both Late Cenomanian-Turonian (lateral equivalents of each other) are younger and overlie the Aptian-Early-Cenomanian Okoyong

\footnotetext{
Corresponding author.
} 
sandstone unit.

Keywords

Cretaceous, Lacustrine, Lithofacies, Mamfe Basin, Palynomorphs

\section{Introduction}

The sedimentary sequences that make up the Mamfe Basin portray a wide range of complex lithologies and lithofacies relationships which hitherto are still to be well understood and defined. The major facies that are frequently encountered include basal and intra-formational conglomerates, sandstone, shale, carbonaceous, and carbonate facies respectively. All these are well exposed at several outcrop sections distributed all over the basin with some measuring up to and above $30 \mathrm{~m}$ in height. These sediments are generally understood to be exclusive of continental origin and the lateral equivalence of the Asu River Group of neighbouring South-eastern Nigerian sedimentary basins all of which are composed of fluvio-lacustrine sediments. Previous authors have worked on various geologic aspects of this basin such as the initiation of the framework of the geological map of the basin [1]-[4]; gravity survey [5]-[8]; audiomagnetotellurics [9]-[11]; aeromagnetic survey [12] [13]; lithostratigraphy [14]-[18]; geochemistry [19]; and general geology [20] [21]. Most of these authors have reported the wide spread occurrences of salts and salt springs and carbonates while [20] reported these and gypsum from the Nfaitok unit.

The widespread occurrence of especially the brines has often put to question the exclusive continental origin of the rocks of this basin, notwithstanding the fact that no purely marine stratum has yet been reported. [22] noted that the two main controlling factors of sedimentation in lakes were the degree of aridity and the amount of sediments supply. But the sediments supply is mostly by rivers which on the other hand depend on climate (temperature and amount and frequency of rainfall), topography and rock types of the surrounding hinterland. Therefore, the ionic precursors of salts in lakes could have been supplied from the chemical composition of the surrounding rocks drained by the rivers supplying the lake water and sediments. However, the Mamfe Basin (Figure 1) is a part (the south-eastern extension into Cameroon) of and is closely associated with the Benue Trough of Nigeria which tectonic and stratigraphic evolutionary history is characterized by repeated marine transgressions.

What then could have been the source(s) of the brines? Genuine suggestions are that, considering the very close proximity and evolutionary history of the Mamfe Basin of Cameroon and the Benue Trough proper of Nigeria, one or more of the marine transgressions into the latter could have extended eastward into the former thus the probable source of the brines. Secondly, the brines could be related to sea water splay into a lagoon or the basin may have been formed as a simple cut-off arm of the sea. Alternatively, the salts may have come in through the atmosphere from a nearby sea and into the lake by precipitation [22]. The lithofacies variations reflect deposition in an equally varied environments and the cyclicity observed indicates frequent water level fluctuation. Several lithostratigraphic frameworks of this basin are in circulation proving that none is generally accepted. No proper lithologic description of the exposed sections is available in literature and the fossil content of the rocks has never been generated and used to date them.

The purposes of the present work are to recover for the first time and use the palynological content of the rock sections well exposed in the eastern part and propose their ages, place the units described herein chronologically and also attempt to reconstruct the paleo-depositional environments on the basis of their lithofacies associations in concert with the palynological data. The fossil content will ascertain the presence or absent of marine sediments among the lithologies studied and this may offer the key divide between a marine or continental source of the brines. The authors hope to contribute considerably towards the gradual construction of a verifiable stratigraphic framework and petroleum exploration activities that have just begun in this basin [23] [24].

\section{Geologic Setting}

Mamfe Basin is an extension of the Benue Trough of Nigeria [5] [9]-[11], which is a major tectono-stratigraphic 


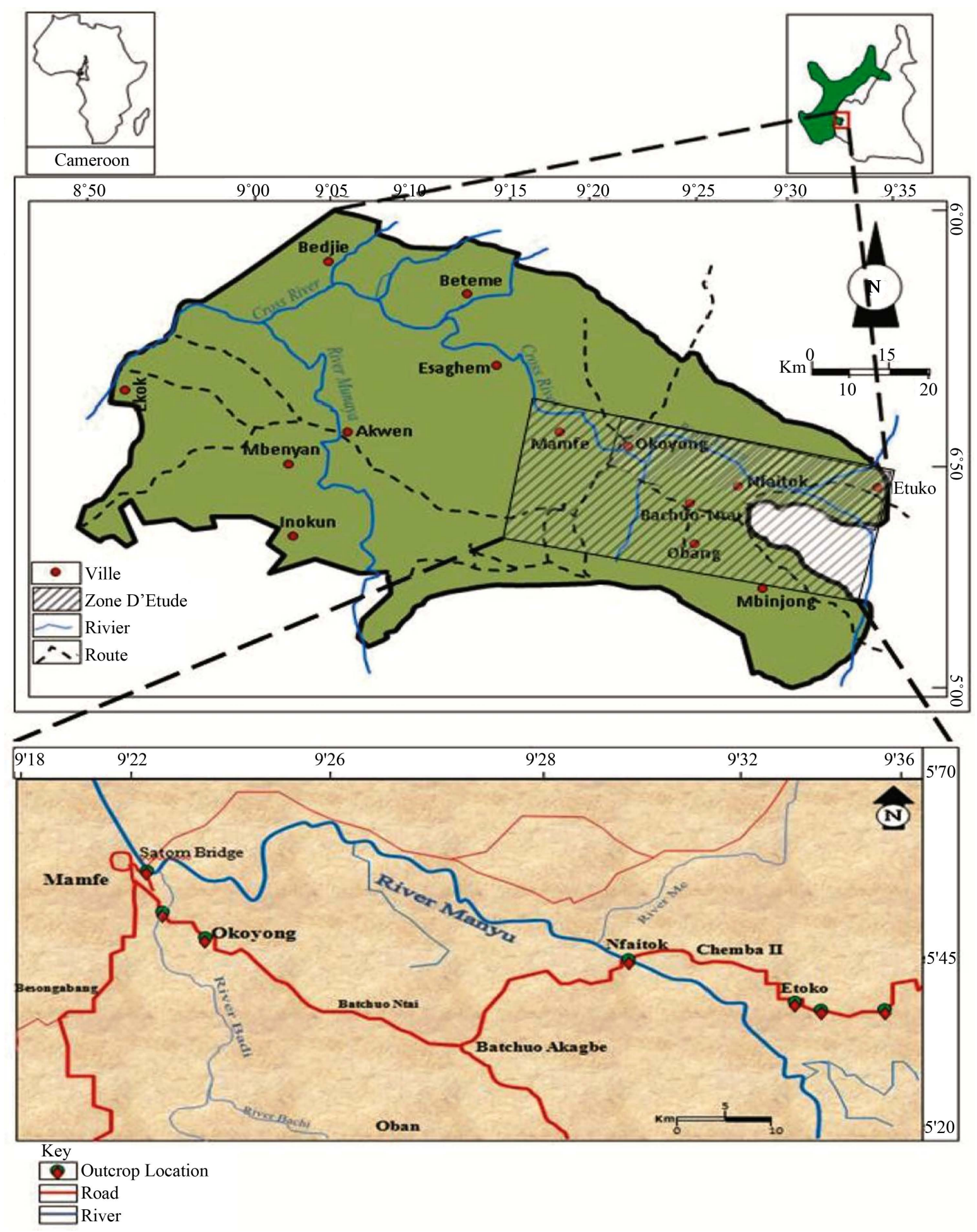

Figure 1. Map of the Mamfe Basin, the study area and the locations of the outcrops encountered during this study (Modified from [4]).

structure on the African continent. It constitutes the southern segment of the "trans-African" lineament, a deep seated zone of weakness that trends NE-SW across Nigeria from the Gulf of Guinea through Niger to Libya and Egypt [5] [14]. It is a part of the West and Central African Rift System (WCARS), an aulacogen that runs over a 
length of about $1000 \mathrm{~km}$ in Nigeria. Two E-W trending basins, the Mamfe and Benue Basins bifurcate off the Benue Trough into Cameroon (Figure 2).

Described as a half graben rift system, the Mamfe Basin straddles the borders of Cameroon into Nigeria where it is referred to as the Mamfe Embayment [25] and outcrops at several roadside cuts along the IkomCalabar Highways. As an arm of the Benue Trough, this basin is equally linked to the WCARS and is closely associated with the opening of the South Atlantic Ocean. Hence, like other basins of the sub-region, Mamfe Basin is formed in response to the Gondwana break-up and the subsequent separation of South America from the African continent [26]-[29]. With a length of about $130 \mathrm{~km}$ and a width of $60 \mathrm{~km}$, the basin is oriented in an almost E-W trending direction [2] [4] and located in the Manyu Division of the Southwest Region of Cameroon. It is bordered in the south by the Oban Massif Precambrian Basement Complex which separates it from the Rio del Rey Basin, to the north by the Precambrian rocks of the Obudu Massif, to the west the Mamfe Basin is open and continues as a part of south-eastern Benue Trough of Nigeria and it narrows and terminates under the Cameroon Volcanic Line (CVL) in the east and northeast (Figure 2).

Gravity anomalies data [5] [8] showed that the basin is made up of a west, middle and east sub-basins respectively and that this basin generally shallows to the east. Dip measurements of the sedimentary strata show that they are dipping between $5^{\circ}$ and $20^{\circ}$ in the SW and NE directions and the several folded ridges that characterize the study area trend in an almost NW-SE direction [1] [3] [4]. The major rivers, the Manyu, Badi, Munaya and Mam are characterized by V-shaped valleys and suggest that uplift is still on-going in this basin. The sedimentary succession is underlain by highly faulted granito-gneissic rocks of the Pan-African Mobile Belt (550 \pm 100 Ma) that form the basement of this region. All rocks in this basin have been intruded by volcanics of the CVL amongst which include; syenites, diorites, trachytes and basalts [1] [4] [15] [17] [18] [30].

Sedimentation began in the Mamfe Basin during the Albian [4] and the resultant sedimentary units are composed of; basal conglomerates, conglomeratic sandstones, mudstones, shales, calcareous and carbonaceous rocks that are highly fractured with a thickness of up to $4000 \mathrm{~m}$. [1] [2] [4] [16] [18] have studied the Lithostratigraphy of the basin (Figure 3). [2] sub-divided the rocks into five units which were denoted as Cg1 to Cg5 in ascending order, while [16] [17] recognized four formations and named them as: Ngeme, Nfaitok (sub-divided into

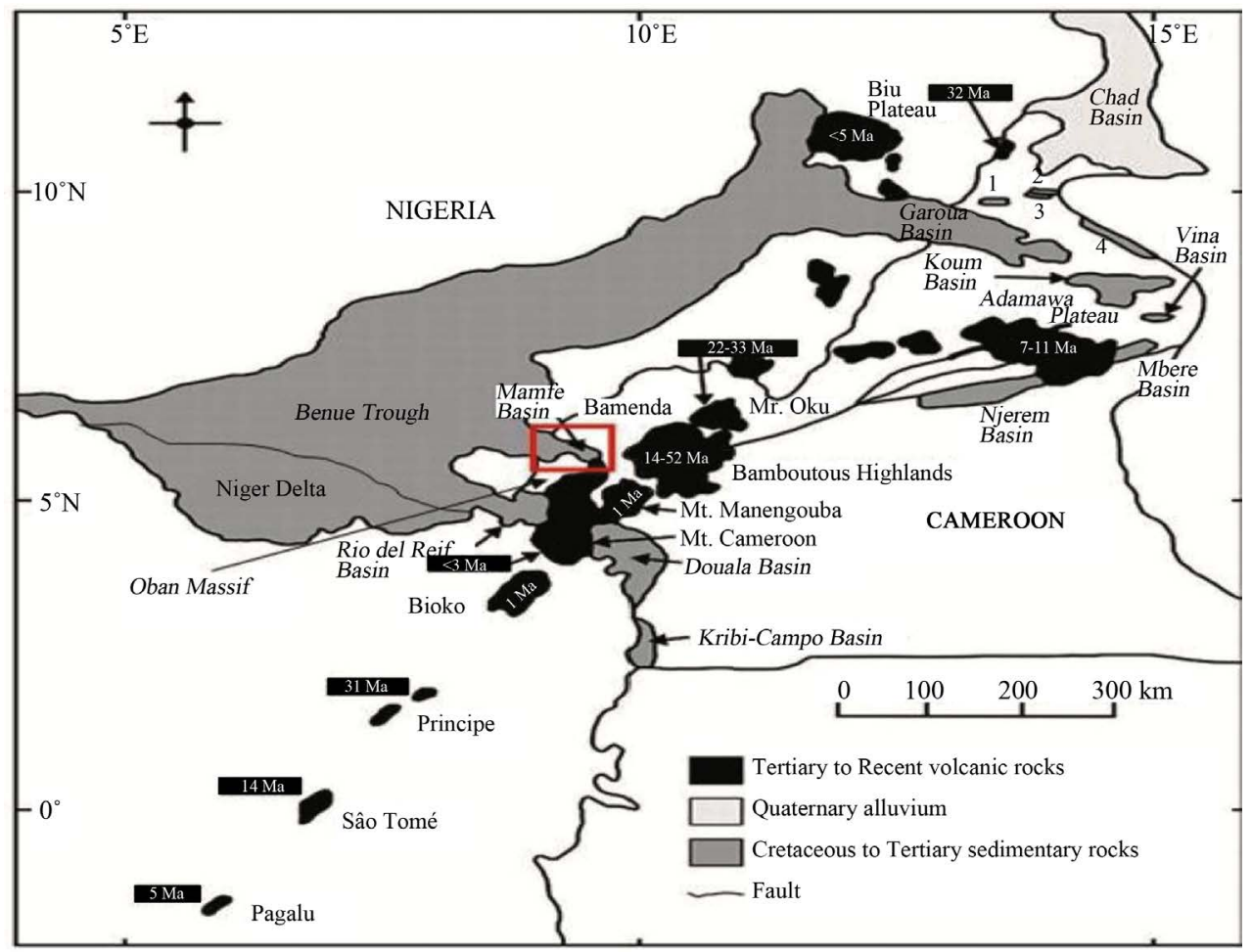

Figure 2. Map showing the relationship between the Benue Trough of Nigeria and the Mamfe Basin of Cameroon, note the Cameroon Volcanic Line and the Garoua Basin of Cameroon to the north (Adopted from [26]). 


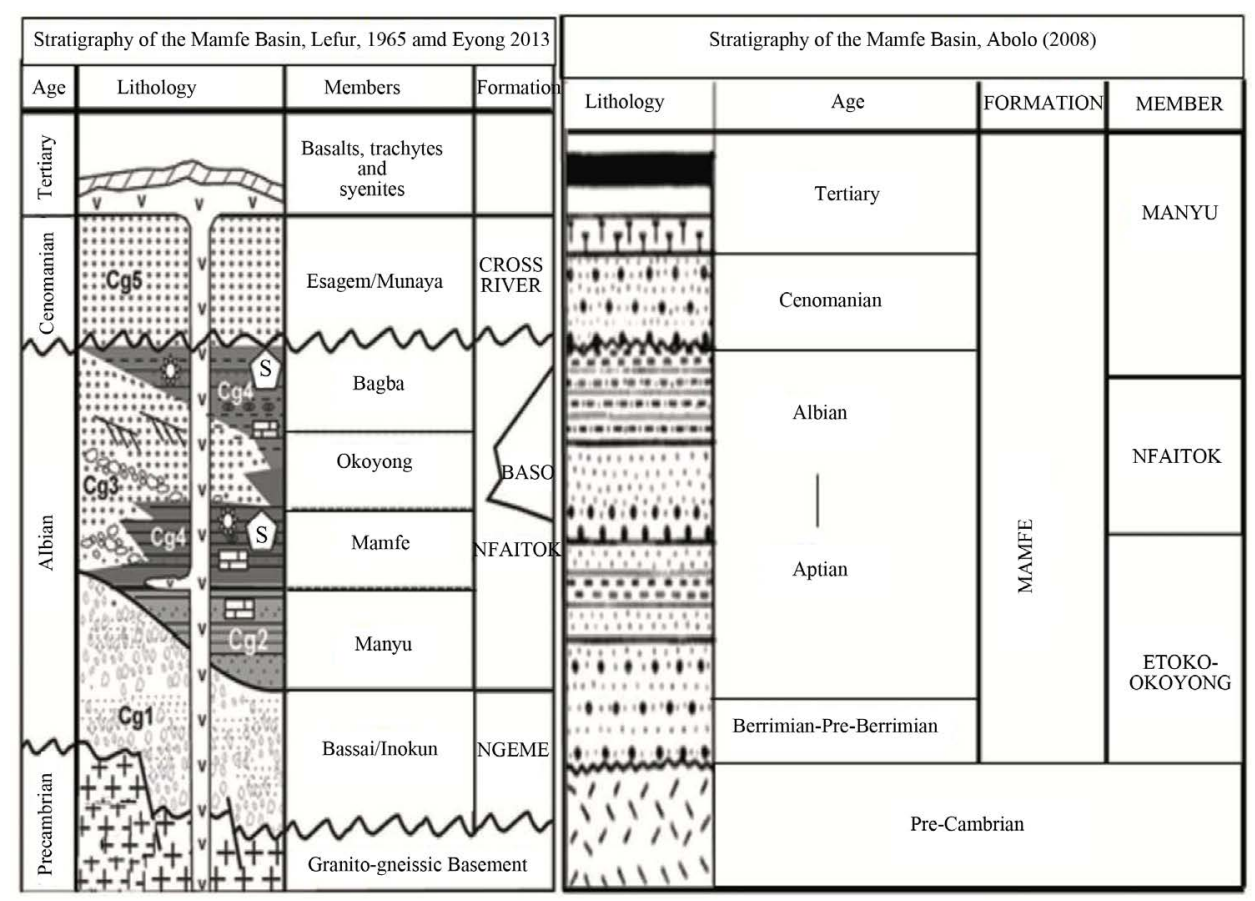

Figure 3. Different stratigraphic frameworks for the Mamfe Basin proposed by [2], restructured by [16]-[18].

members), Baso and Cross-River formations from bottom to top. On the other hand, [18] grouped all the sedimentary rocks in this basin into a single formation, the Mamfe Formation which was subdivided into three members namely, the Etoko-Okoyong, Nfaitok and the Manyu Formations respectively from bottom to top. [2] simply speculated that the Cg1-Cg4 series may be equivalent to the Aptian-Albian Asu River Group of south-eastern Nigeria, while the Cg5 belong to the Cenomanian.

\section{Materials and Methods}

The four outcrop sections selected occur around Etoko mile 21, Nfaitok, Okoyong, Satombridge and the John Holt beach, all within the eastern part of the Mamfe Basin. Etoko herein has been corrected from Etuko and Etuku as referred to in [17] [18] respectively. Geomorphology of some of the outcrop locations necessitated composite sections that were made in order to reveal the successions of rock units. The heights and lateral extension of the outcrops were measured as well as the thicknesses of the beds and structural orientations. The visible vertical physical variations were observed in the field and helped in the identification of the lithofacies associations. As most of the outcrops in this tropical region are densely vegetated and highly weathered, the outcrops were cleaned before studying in detail and samples were collected by hand-digging. The spot sampling method was used but no regular sampling interval was maintained as the fine grained rocks that were sampled do not occur at regular intervals. A total of 32 samples were selected from the shale, siltstone, limestone and marlstone beds and processed for their palynological content.

Standard laboratory techniques for processing and concentrating organic matter were used. It involved the digestion of samples with Hydrochloric acid (35\% - 38\%) and Hydrofluoric acid (40\%) to remove the carbonate and silicate contents of the sediments respectively (Traverse, 1988). This was followed by centrifuging and the use of Zincbromide ( $\mathrm{ZnBr}$ ) with specific gravity 2.2. The samples were thereafter oxidized using conc. Nitric acid $\left(\mathrm{HNO}_{3}\right)$ for a short while before neutralizing with Potassium Hydroxide $(\mathrm{KOH})$. After thoroughly washing with distilled water, the residues were preserved by adding a drop of glycerin to each of well-labeled phials. The samples were then placed on slides and examined under a Zeiss Photomicroscope with a standard stage and at $400 \times$ magnification. Photomicrographs were taken with a digital camera attached to the microscope. The method used here did not preserved most of the dispersed organic matter so a much more simplified scheme for the classification of only the palynomorphs was adopted. From this classification, four palynomorph groups were 
identified namely pollen and spores, freshwater algae, fungal remains and marine palynomorphs.

The lithologic descriptions and the sequence in which they occur were grouped into lithofacies associations and together with the palynological data obtained enabled the interpretation and reconstruction of the paleo-environments of deposition of the sediments studied. A few age diagnostic palynomorphs were recovered among the entire palynological data as well as established assemblages were usedto ascertain the ages of the sedimentary units.

\section{Results}

\subsection{Palynological Data}

A good number of the samples studied were palynoferous but some yielded practically no palynomorphs. Thirty nine palyno-taxa were recovered but not all permitted identification down to species level probably due to poor preservation and most taxa are long-ranging with a few diagnostic forms. The palynomorphs were placed into five groups (Table 1) including pollen grains, Pteridophytic spores, Fungal spores, Archritarch and marine Dinocysts.

Palynomorphs recovered from the Mamfe Basin are dominated by spores of pteridophytes and subordinately gymnosperm pollen grains. While Cicatricosisporites dominates the spores, the Ephedripites and Classopollis form major components of the pollen grains. The entire assemblage is predominated by pollen and spores derived from land plants while marine dinoflagellate cysts occur rarely in a single sample and are dominated by Spiniferites. The diversity and preservation of the palynomorphs are generally poor.

\subsection{Lithologic Description}

Four prominent and representative outcrops were selected and carefully described below. Although each outcrop is unique, their lithologies generally include; intra-formational conglomerates, cross-bedded conglomeratic sandstones, rhythmically bedded to nodular sandstone, shale, limestone and black lignitic shale.

\subsubsection{Etoko Mile 21 Outcrop}

This outcrop is characterized by a frequent alternation of sandstones and shales, occasionally pebbly and nodular with local occurrences of ligniticshales and very thin beds of limestone (Figure 4). With a height of about $13 \mathrm{~m}$, the outcrop extends for over $150 \mathrm{~m}$ and the beds generally dip up to $10^{\circ}$ in the $\mathrm{SW}$ direction. Common sandstone facies, whitish in colour with variable thicknesses and texture pre-dominate this outcrop at the bottom at top. They are massive matrix-supported medium grained, poorly to moderately sorted, sub-rounded and dominantly composed of quartz, and feldspar with tiny flakes of muscovite. These conglomeratic sandstone beds could be up to $68 \mathrm{~cm}$ and include well rounded pebbles and a few boulders, floating in the matrix and both indicate a preferred alignment. Other similar sandstone beds occur except that they are nodular and exhibit faint crossbeddings while others are planar, thinly bedded, showing surfaces of erosion and sole marks.

The shale facies are frequently intercalating the sandstone facies in this outcrop and are generally dark to

Table 1. Description of the various groups of palynomorphs recovered and their quantitative make-up of the entire assemblage.

\begin{tabular}{|c|c|}
\hline Pollen & $\begin{array}{l}19 \text { recovered taxa, } 6 \text { identified species and } 13 \text { only identified down to the genus level and } 1 \text { unidentified form. } \\
\text { The pollen grains here consist of both the gymnosperms represented abundantly by the genus Classopollis and } \\
\text { the angiosperms represented by the genera Retitricolpites and Retimonocolpites all of which are derivatives of } \\
\text { land bearing plants and constitute } 51 \% \text { of the entire palynomorphs assemblage. }\end{array}$ \\
\hline Spores & $\begin{array}{l}\text { These include the miospores from pteridophytic plants which are represented by Cicatricosisporites and } \\
\text { Cyathidites. } 13 \text { taxa of the pteridopytic spores were recovered but only } 6 \text { species were identified and the rest only } \\
\text { down to level of the genus with one unidentified spore all constituting } 45 \% \text { of the entire palynological } \\
\text { assemblage. }\end{array}$ \\
\hline Fungal remains & $\begin{array}{l}\text { Fusiformisporites is the lone fungal spore encountered together with some unidentified fruiting bodies of fungal } \\
\text { origin and filamentous hyphae }(0.6 \%)\end{array}$ \\
\hline Archritarch & The Archritarch are represented by Acrostichumaureum and Leiosphaeridia sp. (0.6\%) \\
\hline Dinoflagilate cysts & $\begin{array}{l}\text { The dinoflagilates cysts are typically represent by the Spiniferites and Lingulodinium sp. with several } \\
\text { unidentifiable Dinoflagellate cysts making up only } 2.8 \% \text { of the entire palynomorphs population. }\end{array}$ \\
\hline
\end{tabular}




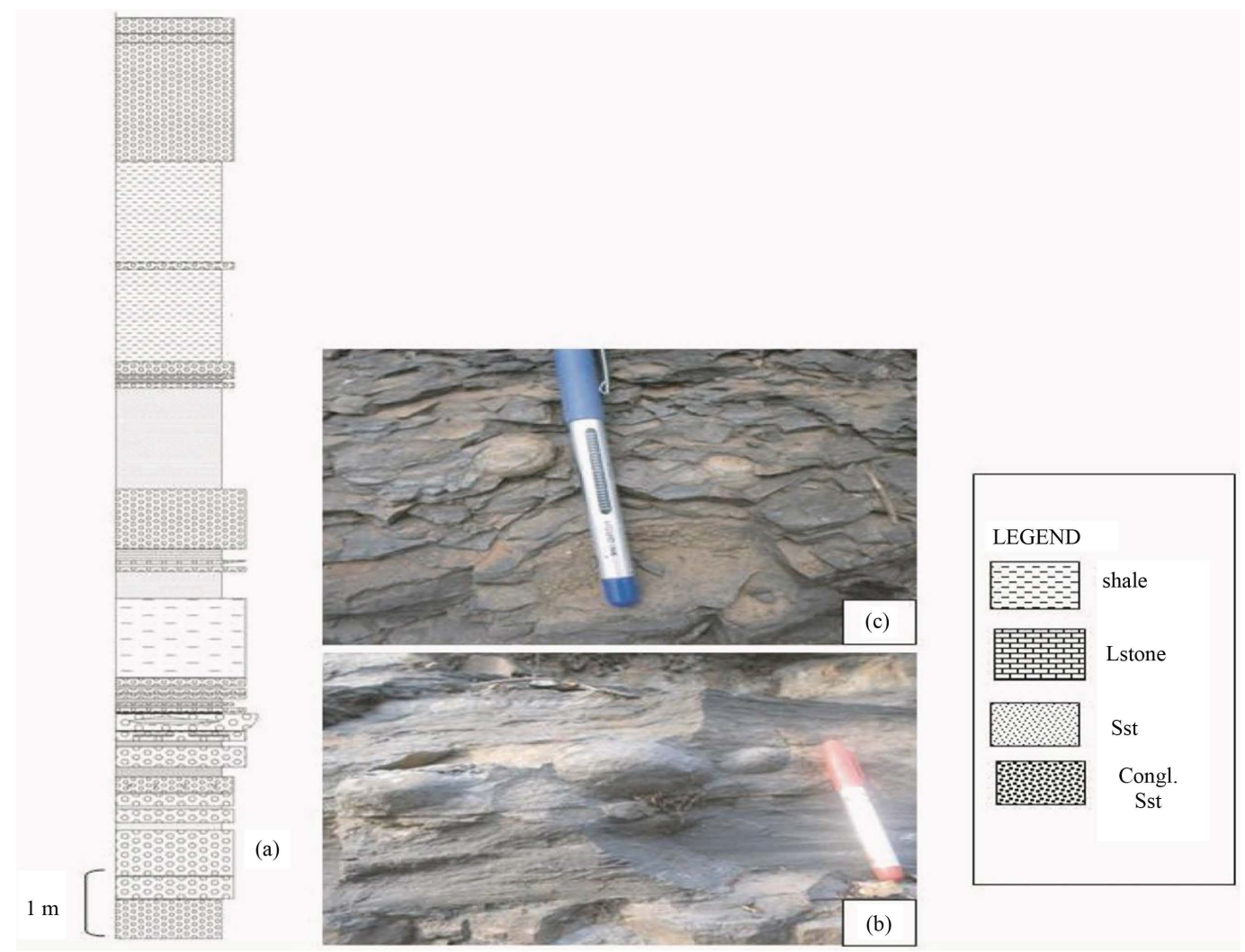

Figure 4. The lothologic log section of the Etoko Mile 21 outcrop and (a) well rounded horizontally aligned pebbles in medium grained sandstone; (b) a nodular shale bed.

black in colour and characterize the middle section of the outcrop. They are massive, indurated, nodular (with the nodules up to and between $1 \times 3 \mathrm{~cm}$ and $2 \times 4 \mathrm{~cm}$ in diameter) and of variable thicknesses $(40-60 \mathrm{~cm})$. Others are characterized by thinly bedded to laminated shale layers, dark-grey, micaceous, sometime very fissile and are not nodular. At the lower and middle sections of this outcrop, lignitic shale facies occur, very black in colour with visible particles of lignite and remains of other organic material. A few but very thin beds of microcrystalline limestone are encountered in between the shale and sandstone beds. This is the least of the facies that is observable at the Etoko mile 21 outcrop (Figure 4).

\subsubsection{Okoyong Sandstone}

The outcrop is a roadside-cut in Okoyong village along the main highway between Bachou-Ntai and Mamfe town. It is about $9 \mathrm{~m}$ high and although it extends along the road for over $300 \mathrm{~m}$, the same lithology is very extensive covering the entire Okoyong, Bijang and Awatu villages respectively and beyond [16] [18], occurring as ridges and is well exposed by the River Manyu which is cutting through and forming an over $30 \mathrm{~m}$ high and steep sided V-shape valley which was inaccessible throughout the period of this field study. Lithologically, the roadside outcrop like the other exposures is dominated by cross-bedded conglomeratic, highly consolidated sandstone layers that are generally whitish in color. Intra-formational conglomerates are equally very prominent especially at the base of most of the conglomeratic sandstones while a few inter-tonguing shale beds with limited lateral extensions irregularly intervening the sandstone beds. The beds are of variable thicknesses but mostly massive and dip generally at an angle of $12^{\circ}$ to the southwest.

The intra-formational conglomerate beds, which are generally repetitive, may show scoured surfaces at the base and the clasts with long axes were laid horizontally and slightly imbricated in places. Some of the beds are clast-supported while others are matrix-supported and in either case, the clasts are perfectly rounded consisting almost entirely of quartz but with a few feldspartic pebbles whose sizes are between $2 \times 4 \mathrm{~cm}$ and $4 \times 7 \mathrm{~cm}$ in diameter and include fine to coarse sand matrix in the case of the matrix supported. Cross-bedded conglomeratic sandstone facies occur repeatedly and overlying the intra-formational conglomerate facies. They are poorly 
sorted, matrix-supported with prominent quartz and feldspar sub-rounded to rounded cobbles and pebble floating in the matrix. The prismatic clasts clearly indicate a preferred directional alignment. This facies is characterized by several sets of planar and trough cross sets and the beds are up to $87 \mathrm{~cm}$ (Figure 5). A generally coarse grained massive matrix-supported sandstone facies is well expressed by the $5 \mathrm{~m}$ thick sandstone bed that caps this roadside outcrop at Okoyong. It is composed of course grains of quartz and feldpars (polygenetic) that are in a matrix of fine to medium grained sandstone and this massive bed is very poorly sorted and the grains are sub-round to round, generally whitish in color.

\subsubsection{Nfaitokunit}

The rocks of this unit extend from Nchemba II village to and around Nfaitok village, and are well exposed on both banks of River Manyu up and downstream. The so called Nfaitok outcrop which represents all the rocks in this locality can best be described using a composite section that comprises those rocks exposed only during the dry on the bed of River Manyu, the rocks that are exposed along the bank of this river and those that are exposed at the roadside-cut above the bridge over the River Manyu at Nfaitok village. [16] described this unit as a separate formation from which the so called Mamfe, Manyu and Ngeme Members were supposedly recognized which is in contrast with [18] that considered it as one of the members that make up the Mamfe Formation. This composite section is well over $30 \mathrm{~m}$ high and dominantly made up of highly indurated dark-grey sometime calcareous shales that are frequently intercalated by limestone and a few intervals of silty and medium to coarse grained sandstone. The beds have an average dip of $10^{\circ} \mathrm{NW}$ with the shale beds ranging between $3-40 \mathrm{~cm}$ in thickness, the limestone and sandstone beds are up to $20 \mathrm{~cm}$ (Figure 6).

\subsubsection{Satom Bridge Outcrop}

This outcrop vertically continue down into the very deep waters of the River Manyu at this point, however, a

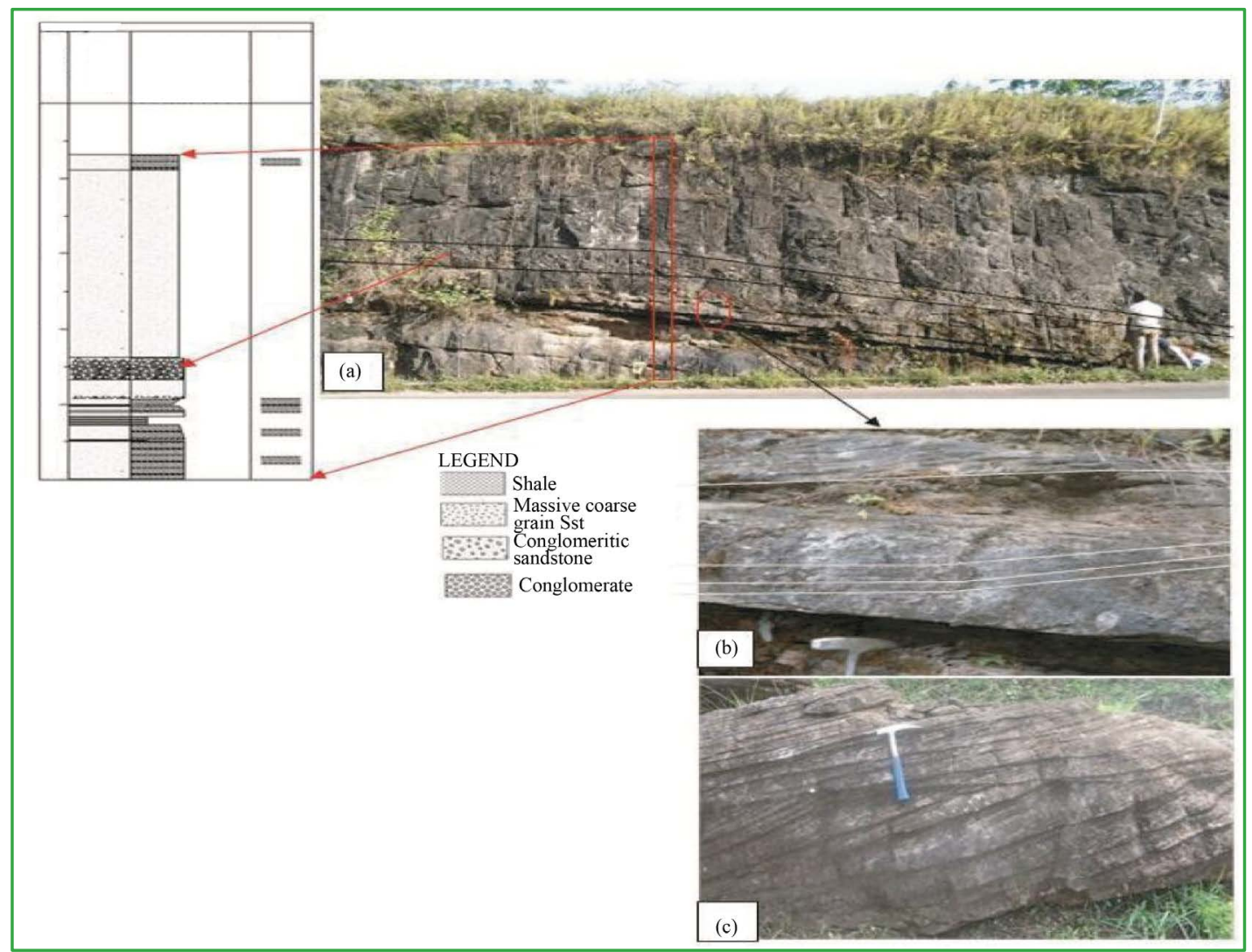

Figure 5. Part of the roadside cut sandstone outcrop at Okoyong village represented by the log section: note in (a), the intervening shale beds, one of the commonly seen intra-formational conglomeratic beds on this outcrop; $\mathrm{b}$ and c exemplifies the planar and trough cross stratifications characteristic of this unit. 

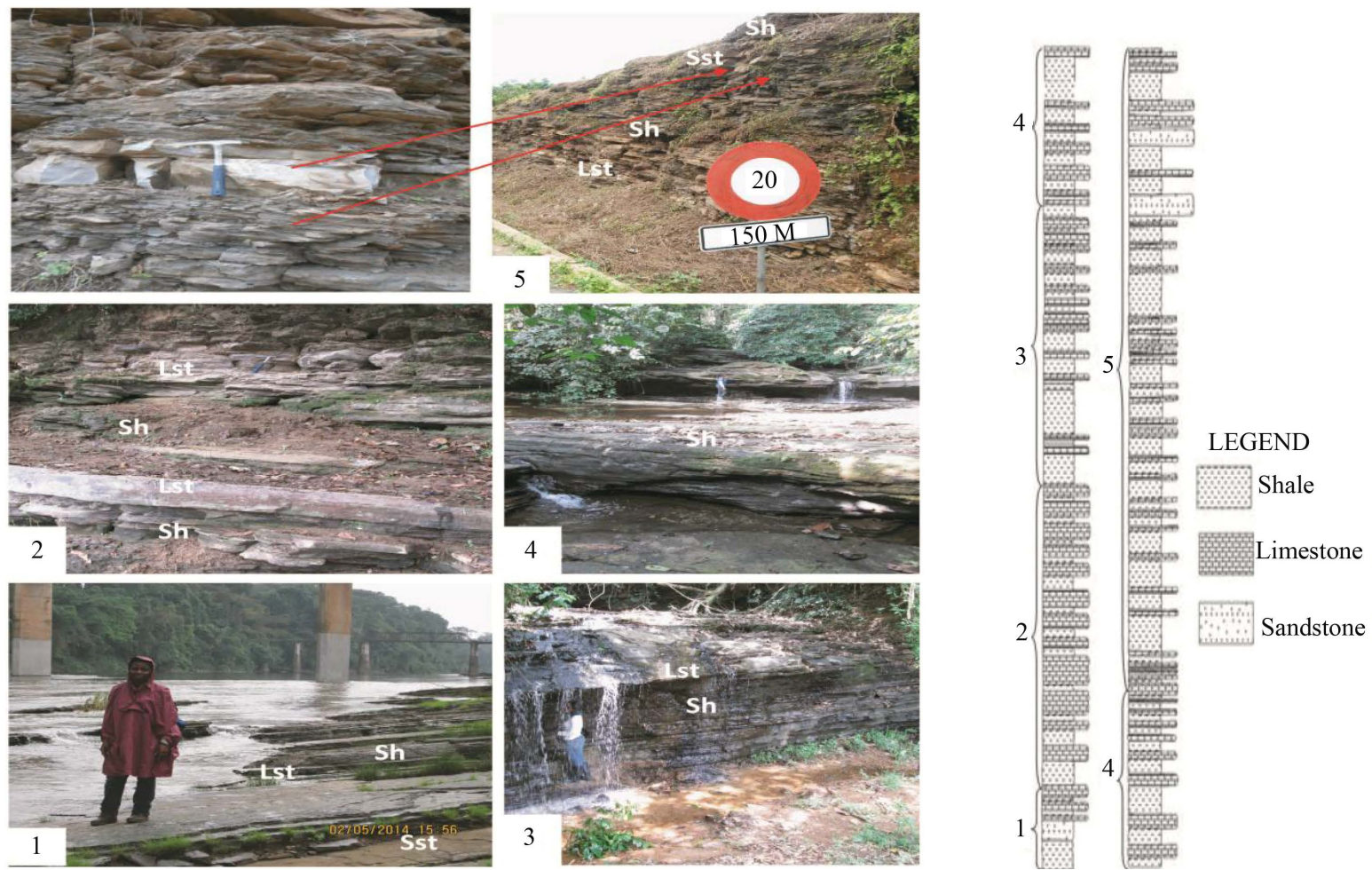

Figure 6. Stacked lithologic sections representing the rock sequence of the Nfaitok outcrop unit which measures above $30 \mathrm{~m}$ in height and starting from the base: 1 showing beds dipping in the NW direction as exposed on the Manyu River bed below the bridge; 2 - 4 are vertical sections observed along the left bank facing upstream of this river near the old bridge seen in the background and 5 is the upper section and the continuation of this outcrop just across the bridge at the Nfaitok village; note the alternations of shale sandstone and limestone at the uppermost part. The composite lithologic log section drawn not to scale but very representative of the over $30 \mathrm{~m}$ thick of sedimentary rocks that make up this unit.

composite section of the part exposed along the river bank is up to $9 \mathrm{~m}$ thick. It is a very heterolithic section composed of alternations of variable thicknesses of beds of shales and limestone which at some intervals, are laminated but generally dipping between $13^{\circ}$ and $15^{\circ} \mathrm{SW}$. The lignitic and highly fissile shale beds can be up to $1.5 \mathrm{~m}$ thick and occupies the lower part of this outcrop. It is very black, organic rich and very fissile and characterized by lignite particles and visible remains of organic particles. Meanwhile, the calcareous shale beds dominate this outcrop and commonly are inter-bedded by limestone laminations and beds of up to $40 \mathrm{~cm}$ thick (Figure 7). These rocks are highly indurated, dark-grey in color and show strong efferversence (Marlstone?). Thin limestone beds are also found inter bedding the lignitic beds.

\subsection{Lithofacies Associations}

Based on the various rock types, textural characteristics and sedimentary structures, five lithologic associations were identified and summarized below (Table 2). Lithofacies association I consists of repetitive intra-formational conglomeratic beds. Lithofacies association II is made up of planar and trough cross-bedded, mediumcoarse grained conglomeratic sandstones which generally overlies the facies association I. Conglomeratic clasts diminish upward as well as the other sand grains, therefore defining a fining-upward sequence. Lithofacies association III consists of massive, very poorly sorted matrix-supported fine-coarse grained sandstone beds of variable thicknesses the thickest measuring up to $5 \mathrm{~m}$.

Lithofacies association IV is compose of the heterolithic rhythmic sequences of alternating beds of highly indurated shale sometimes calcareous sandstone and limestone beds. Lithofacies association V comprises of black organic rich, lignitic and highly fissile shale beds and sometimes inter-bedded with very thin limestone beds or sandstones. This facies association characterizes the Etoko mile 21 and the Satom bridge outcrops. Facies associations I and II is commonly observed at the Okoyong unit while facies association III is absent from the outcrop 

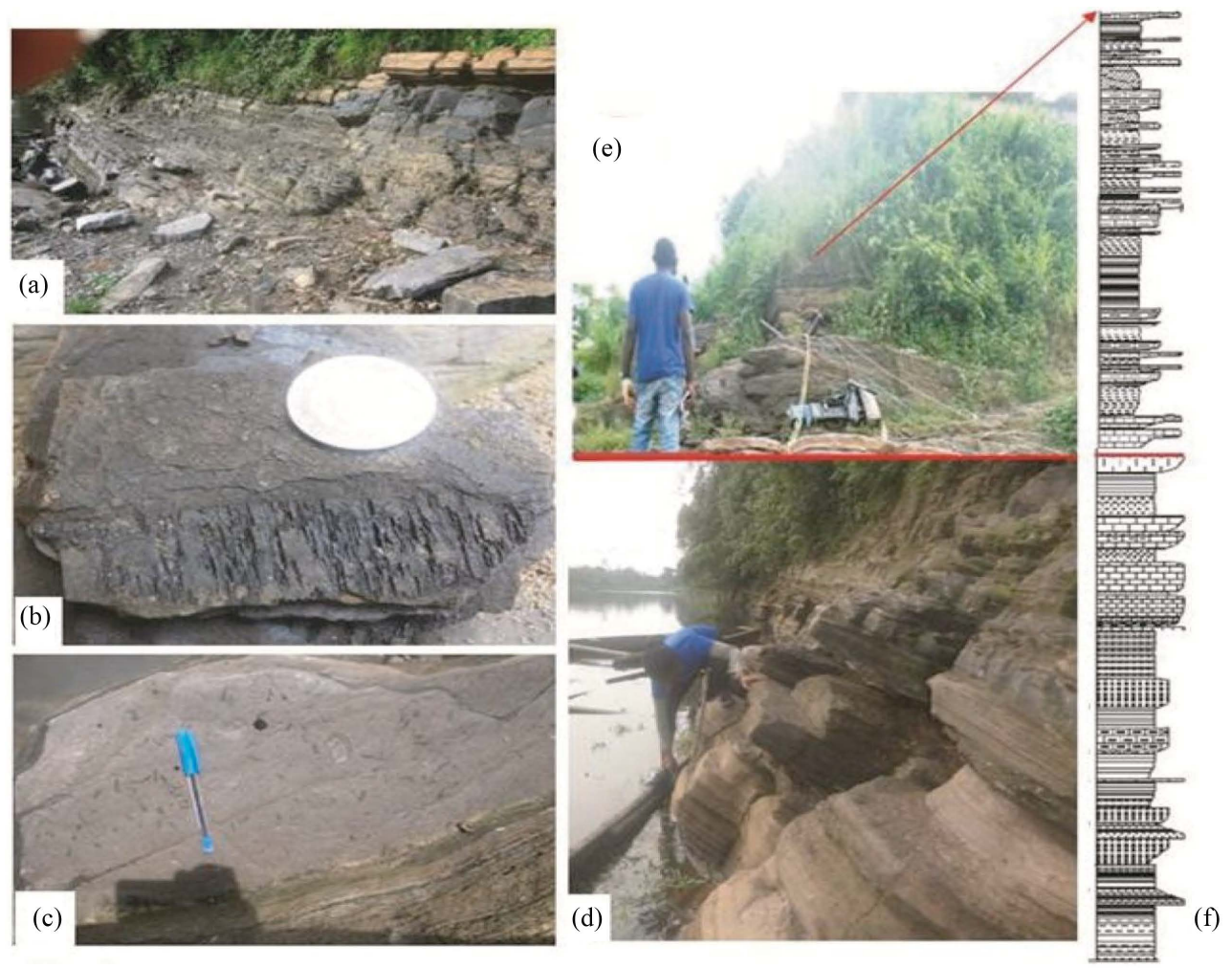

Figure 7. The lithlogic section exposed at the Satom bridge near Mamfe town, represented on a composite log: (a) Liginitic black shales inter-bedded by very thin limestone beds; (b) a hand specimen of lignite; (c) Organic particle remains is shale; (d) the composite log of the entire outcrop.

at the Satom bridge and association IV is common at both the Etoko Mile 21 and Satom bridge outcrops.

\section{Discussion}

\subsection{Age Determination}

Very little has been published on the palynology of sedimentary basins in Cameroon and thus the present analysis is based by comparing with palynolostratigraphy of the basins in Nigeria, Ghana, Cote d'Ivoire, Senegal, Egypt, Libya and Angola in Africa and several genetically linked basins along the east coast of South America. Some of the particularly useful publications include; [31]-[44]. The interpretation made were greatly enhanced by the concept of Barremian-Cenomanian floral provinces [45] re-iterated by [34] in which South America (including Cameroon) were placed in the North Gondwana Province (NGP) and also the Africa South America (ASA) phytogeographical belt established by [32] [33] [46] and re-iterated in [34]. The Early Cretaceous genetic relationship between the South American sedimentary basins and those along the West African coast has been well established on the grounds of the tectonic evolution of these two continents which at the time were still at very close proximity. Only a few short-ranging age diagnostic forms are included in the entire assemblage predominated by their very long-ranging counterparts however, common associations of co-occurring palynomorphs which have been used elsewhere to assign similar ages have also been employed.

Common palynomorphs recovered from the Nfaitok unit include the pollens Classopollis sp., Podocarpidites sp., Retitricolpites sp. And Retimonocolpites sp, the spores include Cicatricosisporites sp., Gleicheniditessenonicus, Dictyophildites harrisi, Deltoidospora mosozoica and Cyathidites sp., while the Dinocysts are mainly Spiniferites. These forms are indicative of early Cretaceous most of which range from Barremian-Aptian to Turonian. [42], recorded Retitricolpites sp. and Classopollis sp. from the El-Waha-1 Well, in the southwestern part of the western desert in Egypt and assigned the sediments to Albian to Cenomanian age. The spiniferites dinocysts, Cyathidites, Retimonocolpites, Gleichniidites, Dictyophillidites are known to occur in other Cretaceous palynomorph assemblages from the Zuata area of Eastern Venezuela [34]. Most of these have also been recovered 
Table 2. The lithofacies associations and palynomorphs assemblages used in inferring the paleodepositional environments for the sediments studied.

\begin{tabular}{|c|c|c|c|c|}
\hline $\begin{array}{l}\text { Lithofacies } \\
\text { association }\end{array}$ & Lithology & $\begin{array}{l}\text { Sedimentary } \\
\text { structures }\end{array}$ & Palynomorphs & $\begin{array}{c}\text { Inferred } \\
\text { environments }\end{array}$ \\
\hline $\mathbf{I}$ & $\begin{array}{l}\text { Multiple intra-formational conglomerate } \\
\text { beds with thicknesses between } 60 \text { and } 80 \\
\mathrm{~cm} \text { and inter-bedded with conglomeratic } \\
\text { sandstones and shale. Comprises of well to } \\
\text { sub-rounded predominantly quartz pebbles, } \\
\text { well to poorly sorted and clasts to matrix } \\
\text { supported. }\end{array}$ & $\begin{array}{l}\text { Parallel aligned } \\
\text { prismatic pebbles, } \\
\text { slightly imbricated } \\
\text { and scoured bottoms. }\end{array}$ & $\begin{array}{c}\text { Practically no } \\
\text { palynomorphs (PNP) }\end{array}$ & $\begin{array}{l}\text { Fluvial channel or } \\
\text { point bars. }\end{array}$ \\
\hline II & $\begin{array}{l}\text { Conglomeratic sandstone beds which } \\
\text { frequently overlies the conglomerate beds. } \\
\text { These beds are poorly sorted, matrix } \\
\text { supported with both the pebbles and sand } \\
\text { sized particles well to sub-rounded, } \\
\text { predominantly quartz and feldspars. }\end{array}$ & $\begin{array}{l}\text { No imbrications but } \\
\text { parallel aligned } \\
\text { prismatic pebbles, } \\
\text { planar and trough } \\
\text { cross-stratification. } \\
\text { Fining upward grain } \\
\text { sizes. }\end{array}$ & No palynomorphs & $\begin{array}{c}\text { Fluvial channel or } \\
\text { point bars }\end{array}$ \\
\hline III & $\begin{array}{l}\text { Massive sandstone beds of variable } \\
\text { thicknesses but up to } 5 \mathrm{~m} \text {. Fine-coarse } \\
\text { grained, poorly sorted, sub-rounded quartz, } \\
\text { feldspars and tiny but visible mica flakes. }\end{array}$ & Structureless & No Palynomorphs & $\begin{array}{c}\text { Lake shore } \\
\text { characterized by } \\
\text { very weak waves. }\end{array}$ \\
\hline IV & $\begin{array}{l}\text { Heterolithic sequence of interbedded } \\
\text { highly indurated shale, limestone, } \\
\text { fine-grained sandstone. The beds vary in } \\
\text { thickness between } 1.5 \text { and } 60 \mathrm{~cm} \text { and } \\
\text { present a rhythmic or cyclic sedimentation. }\end{array}$ & $\begin{array}{l}\text { Thinly bedded to } \\
\text { moderately massive } \\
\text { beds dipping between } \\
10^{\circ}-15^{\circ} \mathrm{NW} \text {. }\end{array}$ & $\begin{array}{l}\text { Mixed palynomorph } \\
\text { assemblages,-Land } \\
\text { derived pollen grains, } \\
\text { pteridophytic spores, } \\
\text { archritarch, algal } \\
\text { remains and } \\
\text { dinoflagellate cysts. }\end{array}$ & $\begin{array}{l}\text { Lacustrine } \\
\text { environment with a } \\
\text { proximal sea water. }\end{array}$ \\
\hline $\mathbf{V}$ & $\begin{array}{l}\text { Massive to fissile, black organic rich, } \\
\text { ligniticshales, sometime occurring and } \\
\text { intercalated with calcareous sediments } \\
\text { (Marlstone). }\end{array}$ & $\begin{array}{l}\text { Sometimes highly } \\
\text { fissile, } \\
\text { Unidentified moulds. }\end{array}$ & $\begin{array}{l}\text { Mixed palynomorph } \\
\text { assemblages,-Land } \\
\text { derived pollen grains, } \\
\text { pteridophytic spores, } \\
\text { archritarch, algal } \\
\text { remains and very } \\
\text { visible plant debris. }\end{array}$ & $\begin{array}{l}\text { Oxygen starved } \\
\text { deep bottom lake } \\
\text { environment. }\end{array}$ \\
\hline
\end{tabular}

from Turonian sediments from the coastal basin in Angola Tunisia and Libya [42]. On the other hand AlbianCenomanian Afropollis jardinus Zone in [47] consists of Afropollis jardinus, Elaterosporites klaszii, Cretacaeiporites scrabatus, C. mulleri, Classopollis braziliansis, Tricolporopollenites sp. Hexaporotricolpitese malianovi and Galeacorneaclavis. This zone which [41] used to assign an Albian-Cenomanian age to the Bima Sandstone of the lower Benue Trough is completely absent from the Nfaitok sediments. The absence of this zone, points to the fact that the sedimentary rocks at Nfaitok village are not older than the Cenomanian. Hence, the age of these rocks are suggested to be Late Cenomanian to probably Early Turonian (Figures 8(a)-(c)).

The palynomorphs recovered from the Satom Bridge outcrop are characterized by two forms Cicatricosisporites sp. and Classopollis sp. Their association with a Late Cenomanian-Turonian index form, Trioritesafricaensis, also strongly suggests a Late Cenomanian to probably Early Turonian age for these sediments thus implying that this section is the lateral age equivalent of the Nfaitok unit. The Okoyong outcrop palynomorphs are also dominated by Cicatricosisporites sp. and Classopollis sp. both of which co-occur with Ephedripites jansonii which is an index form that characterizes the Aptian-Cenomanian age and did not range beyond Cenomanian (Figure 9). Ephedripites were very common and diversified in the lower Creataceous (Aptian-Cenomanian) floral assemblage in Peru, Brazil, West Africa and Israel [34]. Diverse occurrences of Classopollis and Ephedripites commonly among the palynomorph assemblage recovered from the sediments along Ediki River in the Douala Basin were dated Albian-Cenomanian [44]. This association suggests that the outcrop at Okoyong is older than those of the Nfaitok and Satom Bridge and has been dated Aptian-Early-Cenomanian or possibly Berrimian. The palynomorphs yielded from the Etoko mile 21 outcrop are very poor and include amongst others, Classopollis and Cicatricosisporite., However, these forms were not convincing enough to assign a particular age to this stratigraphic section which undoubtedly Early Cretaceous. 


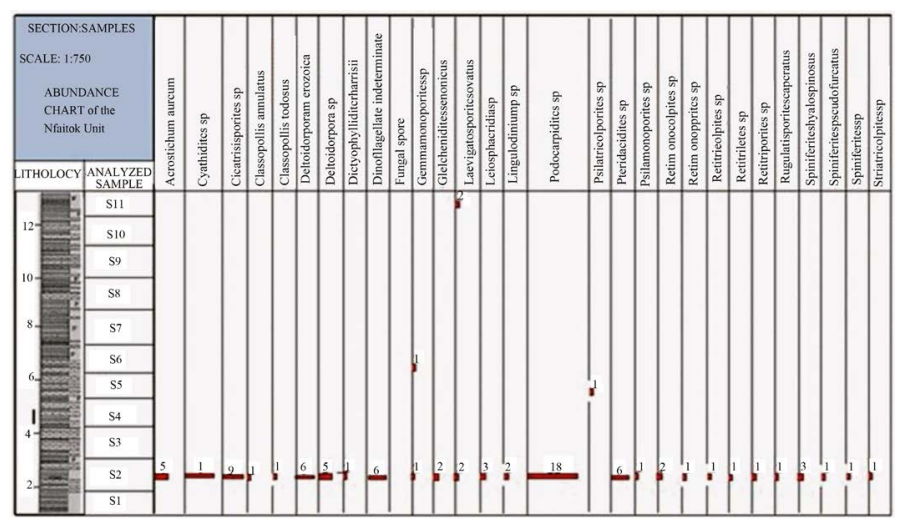

(a)

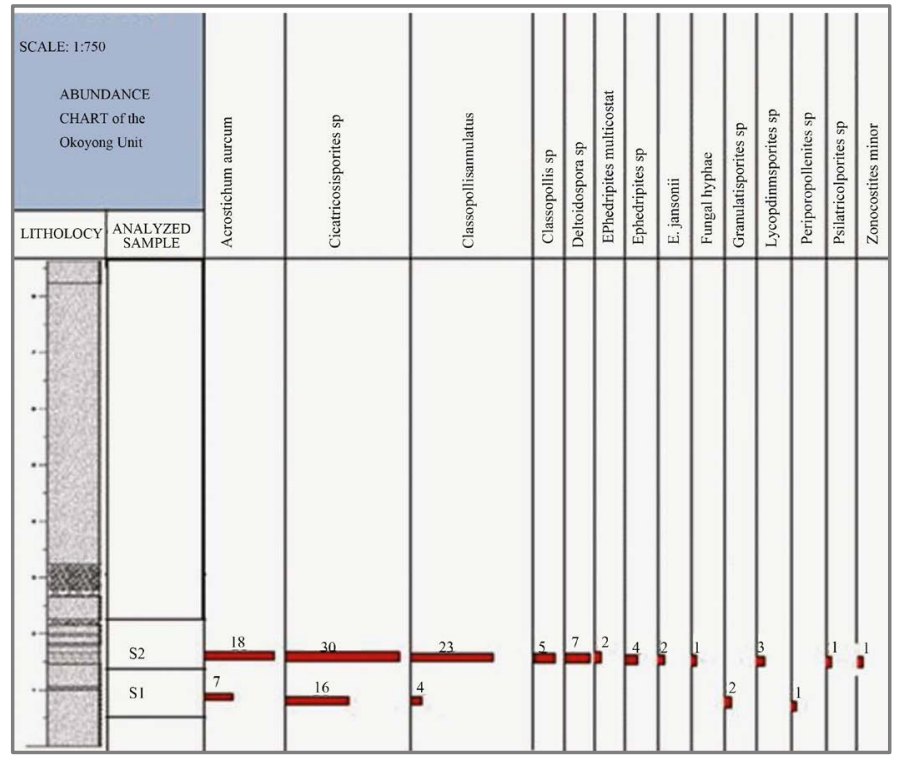

(b)

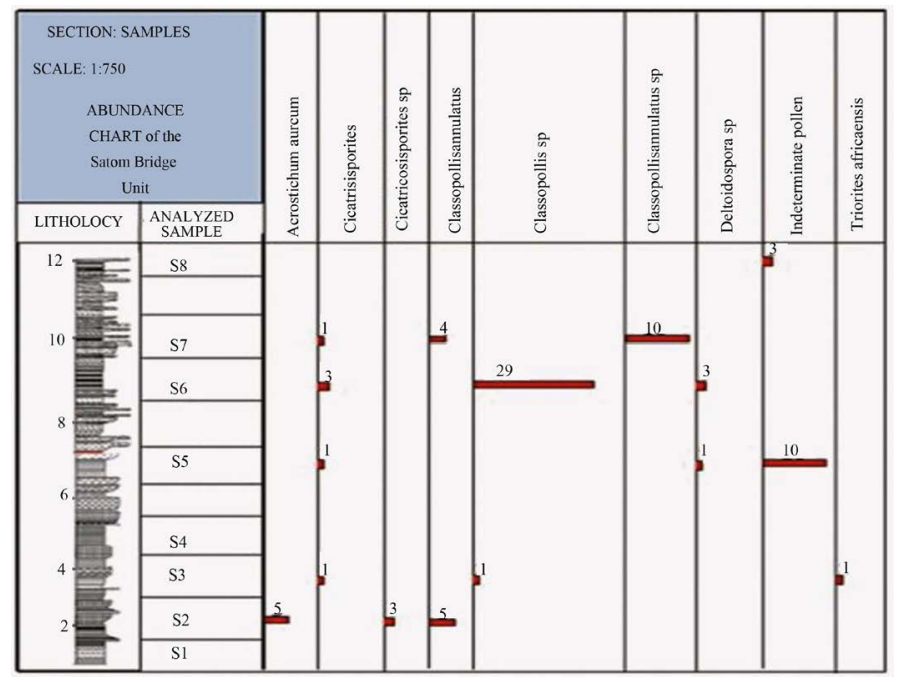

(c)

Figure 8. (a)-(c) Palynomorphs distribution charts of the palynoferous intervals at Nfaitok, Okoyong and Satom bridge outcrops respectively. 

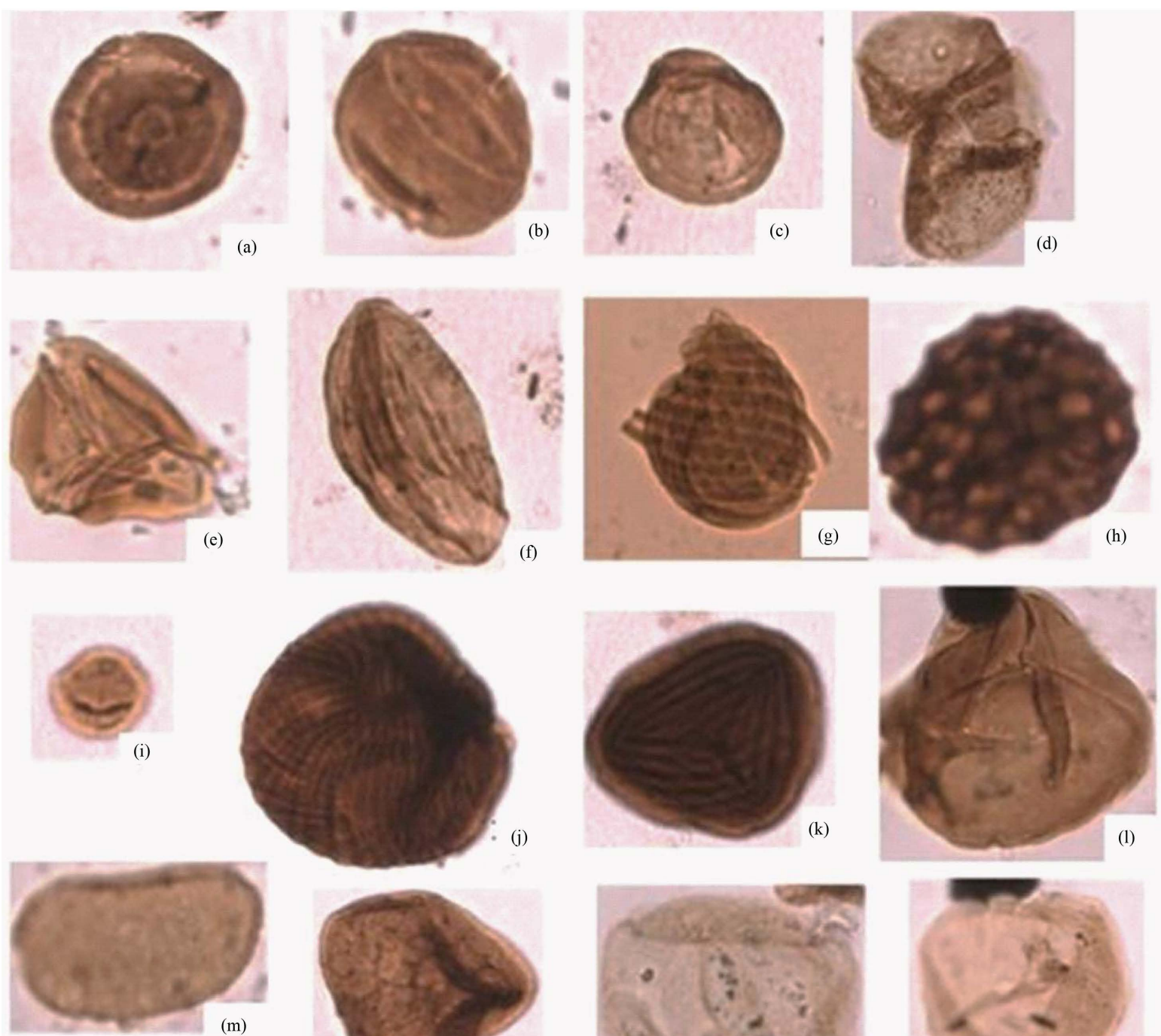

(m)
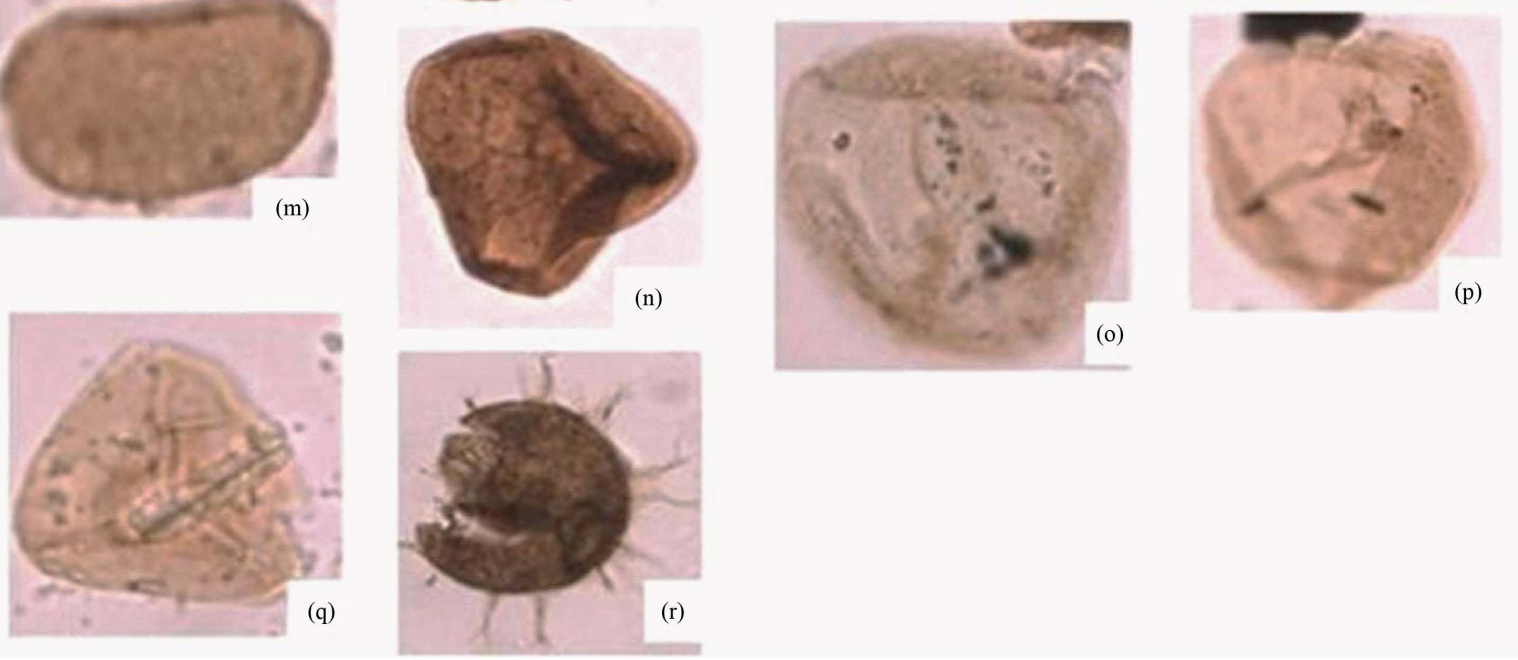

(o)

(p)

Figure 9. All ×800: (a) Classopollis todosus (b) Classopollis sp., (c) Classopollis annulatus, (d) Podocarpidites sp., (e) Pteridacidites sp., (f) Ephedripites multicostatus, (g) Ephedripites jonsonii, (h) Pteris sp., (i) Zonocostites minor, (j) \& (k) Cicatricosisporites sp., (l) Acrostichum aureum, (m) Laevigatosporites sp., (n) Lyocopodiumsporites sp., (o) \& (p) Leiosphaeridia sp., (q) Cyathidites sp., and (r) Spiniferites hyalospinosus.

\subsection{Paleodepositional Environment}

The environments and depositional conditions under which these sedimentary units were deposited were interpreted based on the lithofacies associations recorded from the sections studied. The palynological data obtained from the shale and limestone intervals have equally been used to support to the paleoenvironmental interpreta- 
tions with the understanding that pollen and spores produced from land bearing plants far off from the shores can be transported by wind and run-offs into water bodies (lakes and oceans) as their marine counterpart could only have been brought into transitional environments by storms and creeks [40] [48].

The entire palynological assemblage obtained from the sediments studied in this work is generally characterized by spore and pollen derivatives of land plants. The species Acrostichum aureum and other fern spores are commonly found in fresh water swamps while the other palyno-ecological communities comprise of those from the savanna and forest areas. However, the general absence of the marine palynomorphs (The dinoflagellate cysts and foraminiferal linings) from the samples coupled with relative high percentages of the Classopollis and Ephedripites species, suggest a shallow water, non-marine depositional environment. A few dinoflgellate cysts were recordedonly from a single interval at the Nfaitok outcrop and are characterized mainly by the spiniferites (Figure 8(a)). While suspecting the influence of a probable nearby marine water body during the deposition, the sediments from this particular interval yielded practically no foraminifera. Foraminifera, is one of the groups of microfossils that are exclusively marine and therefore constitutes a strong diagnosis of marine strata. Its total absence coupled with the scanty appearance of the spinifirites and the predominance of the typical land derived pollen and spores suggest that the sediments at this interval are not truly marine in origin. Rather, it supports the idea proposed by [49] of the existence of an Ikom ridge over which water from the then Benue sea periodically spilled during high storms into the lacustrine setting and most undoubtedly floating overboard the scanty occurrence of the dinocysts.

Fluvial deposits: lithofacies association I and II have been interpreted to represent a fluvial deposit. The intra-formational conglomerates associated with scoured bases reflect channel or point bar deposits and at the Okoyong roadside cut this facies is occurs repeatedly. At this outcrop, the lithofacies association II overlies the association I at all the levels with their cross beds and preferred directional alignment of pebbly clasts indicating the paleo-flow direction. Following the model of [50] [51], this facies which is normally graded represent a typical fining upward sequence of the upper regime of the channel deposit. Two intervals were observed to reflect a reversed flow direction which is thought to be a transitional environment affected by tidal currents as the river empties into large water body.

Fluvio-deltaic deposits: Lithofacies association III is a massive poorly sorted medium to fine grained sandstone which suggests a lake shore deposit where the river was emptying its sediment supplies but the waves were probably not strong enough to redistribute them. Bottom Lake deposits: [52] described bottom deposits of large lakes to consist of predominantly fine grained materials as siltstone, fine sandstone and mudstone. Facies association IV and V represent in this study a repetitive or rhythmic sedimentation whereby the finer material seemed to have been winnowed from the shore by weak waves or passed the deltas carried by water with mixed organic matter and precipitate commonly Calcium Carbonate $\left(\mathrm{CaCO}_{3}\right)$. These lithofacies associations are commonly thinly bedded and laminated in places alternating between shale, silt, and limestone. Water level fluctuations, clastic sediment supply and climate variation may have influence this deposition. Hence when sediment supply is low, calcareous material from algae and calcareous organisms may be precipitated to form limestone beds and or marl. Organic material in an oxygen-deficient bottom may have contributed to form the black lignitic shale encountered (Figure 7).

\section{Conclusions}

Palynomorphs from Cretaceous sedimentary sequences in the Mamfe Basin have for the first time been recovered and used in determining the ages of some exposed strata. Based on this data, an Aptian-Late Cenomanian age has been confirmed for the exposed sections studied and their stratigraphic sequence revealed that the Aptian-Early-Cenomanian Okoyong unit was older than and was overlain by the two age equivalent Late Cenomanian Nfaitok and Satom bridge units. The palynomorphs recovered from these sediments are generally derivatives of land plants indicating a continental fluvio-lacustrine environment of deposition. The fact that the dynocysts recovered are so few and most have been from a marine origin seems to support the suggestion that at one time or the other in the history of this basin, sea water which must have been at close proximity, splayed over a barrier and into the basin. However, since no true marine sediments as was expected have been revealed yet in this study, we suggest here that the accumulation of sea water splayed over a barrier (Ikom ridge) into a lacustrine setting may have partly been a source of the brines. The existence of the Ikom ridge proposal of [49] and strongly supported in this work coupled with no evidence of any true marine strata in the Mamfe Basin (IkomMamfe Embayment) may necessitate the idea of the deposition of metacarbonate rocks [53] in an shallow ma- 
rine environment in the Mamfe Embayment, to be revisited.

The palynomorph assemblage suggests arid conditions during this early to middle Cretaceous times. This climatic condition could have facilitated the precipitation of such salts which could have also received considerable contributions from the chemistry of the surrounding crystalline rocks that were drained. Sedimentological analyses have provided evidence that these sediments were deposited in a fluvio-lacustrine-deltaic and anoxic bottom environment. The lithologies, sedimentary structures and facies associations are diagnostic for the paleo environments of deposition. Common lithologies encountered within the sections studied are the intra-formational conglomerates, cross-bedded conglomeratic sandstone, nodular sandstone and shale, calcareous and black organic rich fissile and lignitic shale and limestone. Based on the palynomorphs analysis, the age of the section exposed at Etoko mile 21 could not be determined with certainty since the forms were too scanty and comprised only of very long-ranging non-age diagnostic forms. However, the few Cicatricosisporites and Classopollis species are suggestive of a Cenomanian-Turonian in age. As a beginning of a systematic investigation of the stratigraphy of the Mamfe Basin, the authors hope to progressively come out with details that will culminate in setting up a reliable and verifiable stratigraphic frame for the basin and may eventually also answer the question whether this basin actually contains marine sediments or not.

\section{Conflict of Interest}

This research is an original work that has been carried out by us and we the authors declare that there is no conflict of interests regarding the publication of this manuscript.

\section{Acknowledgements}

The authors acknowledge the various sets of students from the Universities of Buea, Bamenda, Douala and those from the Cameroon Christian University, Bali for the assistance in hand-digging the pits from which samples were collected. Mr Emmanuel Bassey and the team of laboratory technicians at South-sea Petroleum Company, Port-Harcourt, Nigeria are equally appreciated for providing the Laboratory space and equipments and Mr. Taku Agbor Jr., Njoke Lionel and Njeng Napoleon, who assisted with some of the figures.

\section{References}

[1] Wilson, R.C. (1928) Notes on the Geology of the Mamfe Division, Cameroon Province. Occasional Paper, Geology Survey of Nigeria, 6 p.

[2] Le Fur, Y. (1965) Rapport spécialsur les recherches de corindonsgemmes. Mission socle-crétacé, Mamfé YAO 666A8. Archives Bureau des Recherches Geologiqueet Minieres, 69 p.

[3] Collignon, F. (1968) Gravimétrie de reconnaissance de la République Fédérale du Cameroun. Raport (Ostrom), Paris, 16 p.

[4] Dumort, J.C. (1968) Carte géologique de reconnaissance et note explicative sur la feuille Douala-Ouest (1:500000). République Fédérale du Cameroun, Direction des Mineset de la Géologie du Cameroun, 69 p.

[5] Fairhead, J.D. and Okereke, C.S. (1987) A Regional Gravity Study of the West African Rift System in Nigeria and Cameroon and Its Tectonic Interpretation. Tectonophysics, 143, 141-159. http://dx.doi.org/10.1016/0040-1951(87)90084-9

[6] Airhead, J.D., Okereke, C.S. and Nnange, J.M. (1991) Crustal Structure of the Mamfe Basin, West Africa, Based on Gravity Data. Tectonophysics, 186, 351-358. http://dx.doi.org/10.1016/0040-1951(91)90368-3

[7] Ndougsa-Mbarga, T. (2004) Etude géophysique par méthodegravimétrique des structures profondesetsuperficielles de la region de Mamfé. Thèse Doctorat, Faculté. Sciences, Université Yaounde I, Yaoundé, 255 p.

[8] Ndougsa-Mbarga, T., Manguelle-Dicoum, E., Campos-Enriquez, J.O. and Atangana, Q.Y. (2007) Gravity Anomalies, Sub-Surface Structure and Oil and Gas Migration in the Mamfe, Cameroon-Nigeria, Sedimentary Basin. Geofísica Internacional, 46, 129-139.

[9] Nguimbous-Kouoh, J.J., Takougam, E.M.T., Nouayou, R., Tabod, C.T. and Manguelle-Dicoum, E. (2012) Structural Interpretation of the Mamfe Sedimentary Basin of Southwestern Cameroon along the Manyu River Using Audiomagnetotellurics Survey. Geophysics, 2012, Article ID: 413042.

[10] Nouayou, R. (2005) Contribution à l'étudegéophysique du bassinsédimentaire de Mamfe par prospections audio et héliomagnétotelluriques, M.Sc. Thesis, spécialité Géophysique Interne, Université de Yaoundé I, Yaoundé, 60 p.

[11] Tabod, C.T., TokamKamga, A.P., Manguelle-Dicoum, E., Nouayou, R. and Nguiya, S. (2008) An Audio-Magnetote- 
lluric Investigation of the Eastern Margin of the Mamfe Basin, Cameroon. The Abdus Salam International Centre for Theoretical Physics, Trieste, 15 p.

[12] Kangkolo, R. and Ojo, S.B. (1995) Integration of Aeromagnetic Data over the Mamfe Basin of Nigeria and Cameroon. Nigeria Journal of Physics, 7, 53-56.

[13] Kangkolo, R. (2002) Aeromagnetic Study of the Mamfe Basalts of Southwestern Cameroon. Journal of the Cameroon Academy of Sciences, 2, 173-180.

[14] Petters, S.W. (1978) Stratigraphic Evolution of the Benue Trough and Its Implication for the Upper Cretaceous palaeogeography of West Africa. Journal of Geology, 86, 311-322. http://dx.doi.org/10.1086/649693

[15] Ajonina, H.N., Ajibola, O.A. and Bassey, C.E. (2002) The Mamfe Basin, SE Nigeria and SW Cameroon: A Review of the Basin Filling Model and Tectonic Evolution. Journal of the Geoscience Society of Cameroon, 1, 24-25.

[16] Eyong, J.T. (2003) Litho-Biostratigraphy of the Mamfe Cretaceous Basin, SW Province of Cameroon-West Africa. $\mathrm{PhD}$ Thesis, University of Leeds, Leeds, $256 \mathrm{p}$.

[17] Eyong, J.T., Wignall, P., Fantong, W.Y., Best, J. and Hell, J.V. (2013) Paragenetic Sequences of Carbonate Rocks and Sulphide Minerals of the Mamfe Basin (Cameroon): Indicators of Paleo-Fluids, Paleo-Oxygen Levels and Diagenetic Zones. Journal of African Earth Science, 86, 25-44.

[18] Abolo, M.G. (2008) Geology and Petroleum Potential of the Mamfe Basin, Cameroon, Central Africa. Africa Geoscience Review, 65-77.

[19] Eseme, E., Agyingi, C.M. and Forba, T. (2002) Geochemistry and Genesis of Brine Emanations from Cretaceous Strata of the Mamfe Basin, Cameroon. Journal of African Earth Science, 35, 467-476. http://dx.doi.org/10.1016/S0899-5362(02)00171-9

[20] Eben, M. (1984) Aspect géologue du golfe de Mamfe, Campagne 1983-84. Rapport Bureau des Recherches Geologiqueet Miniere, $106 \mathrm{p}$.

[21] Hell, J.V., Ngako, V., Bea, V., Olinga, J.B. and Eyong, J.T. (2000) Rapport des travauxsurl'étude de reconnaissance géologique du bassinsédimentaire de Mamfé. Raport technique, Instutute des Recherches Geologiqueet des MinieresSocieté Nationale Hydrocarbure, 76 p.

[22] Selley, C.R. (1982) An Introduction to Sedimentology. Academic Press, London, 417 p.

[23] Stendal, H., Toteu, F.S., Frei, R., Penaye, J., Njel, O.U., Bassahak, J. and Hell, V.J. (2006) Derivation of Detrital Rutile in Yaoundé Region from Cameroon the Neoproterozoic Pan-Africain Belt in Southern Cameroon (Central Africa). Journal of African Earth Sciences, 44, 443-458. http://dx.doi.org/10.1016/j.jafrearsci.2005.11.012

[24] Kanouo, N.S., Yongue, R.F., Chen, S., Njonfang, E., Ma, C., Ghogomu, T.R., Zhao, J. and Sababa, E. (2012) GreyishBlack Rutile Megaclasts from the Nsanaragati Gem Placer, SW Cameroon: Geochemical Features and Genesis. Journal of Geography and Geology, 4, 134-146. http://dx.doi.org/10.5539/jgg.v4n2p134

[25] Petters, S.W., Okereke, C.S. and Nwajide, C.S. (1987) Geology of the Mamfe Rift. In: Matheis, G. and Schandelmeier, H., Eds., Current Research in African Earth Sciences, Balkema, Rotterdam, 299-302.

[26] Benkhelil, J. (1989) Origin and Evolution of the Cretaceous Benue Trough of Nigeria. Journal of African Earth Science, 8, 251-282. http://dx.doi.org/10.1016/S0899-5362(89)80028-4

[27] Green, H.T. (1995) Significance of Nb/Ta as an Indicator of Geochemical Process in the Crust-Mantle Systern. Chemical Geology, 120, 347-359. http://dx.doi.org/10.1016/0009-2541(94)00145-X

[28] Genik, G.J. (1993) Petroleum Geology of Cretaceous-Tertiary Rift Basins in Niger, Chad and Central African Republic. American Association of Petroleum Geologists Bulletin, 77, 1405-1434.

[29] Petters, S.W., Nyong, E.E., Akpan, E.B. and Essien, N.U. (1995) Lithostratigraphic Revision of the Calabar Flank. 31st Annual Conference, Calabar, 15-18 March 1995, Nigerian Mining and Geological Society, 54.

[30] Njonfang, E. and Moreau, C. (1996) The Mineralogy and Geochemistry of a Sub-Volcanic Alkaline Complex from the Cameroon Line: The Nda-Ali Massif, South West Cameroon. Journal of African Sciences, 22, 113-132. http://dx.doi.org/10.1016/0899-5362(96)00126-1

[31] Jardine, S., Kieser, G. and Reyre, Y. (1974) L'individualisation progressive du continent Africainvue à travers les donnéespalynologiques de 1’ère secondaire. Scieté Géologique Bulletin, 27, 69-85.

[32] Herngreen, G.F.W. (1973) Palynology of Albian-Cenomanian Strata of Borehole 1-QS-l-MA, State of Maranhao, Brazil. Pollen et Spores, 15, 515-555.

[33] Herngreen, G.F.W. (1975) Palynology of Middle and Upper Cretaceous Strata in Brazil, Meded. Rijks Geologische Dienst, 26, 39-91.

[34] Sinanoglu, E. (1984) Early Cretaceous Palynomorphs from Zuata Area, Eastern Venezuela. Boletim IG-USP. Série 
Científica, 15, 116-128. http://dx.doi.org/10.11606/issn.2316-8986.v15i0p116-128

[35] Schrank, E. (1991) Mesozoic Palynology and Continental Sediments in NE Africa (Egypt and Sudan) —A Review. Journal of African Earth Science, 12, 363-373. http://dx.doi.org/10.1016/0899-5362(91)90085-D

[36] Schrank, E. (2001) Paleoecological Aspects of Afropollis/Elateratespeaks (Albian-Cenomanian Pollen) in the Cretaceous of Northern Sudan and Egypt. In: Goodman, D.K. and Clarke R.T., Eds., 11th International Proceedings, Palynological Congress, American Association of Stratigraphers and Palynologists Foundation, Houston, 201-210.

[37] Schrank, E. and Ibrahim, M.I.A. (1995) Cretaceous (Aptian-Maestrichtian) Palynology of Foraminifera-Dated Wells (KRM-1, AG-18) in Northwestern Egypt. Berliner Geowissenschaftlische Abhandlungen (A), 177, 1-44.

[38] Moullade, M., Watkins, D.K., Oboh-Ikuenobe, F.E., Bellier, J.P., Masure, E., Holbourn, A.E.L., Erbacher, J., Kuhnt, W., Pletsch, T., Kaminski, M.A., Rauscher, R., Shafik, S., Yepes, O., Dejax, J., Gregg, J.M., Shin, I.C. and schuler, M. (1998) Mesozoic Biostratigraphic, Paleoenvironmental and Paleobiogeographic Synthesis, Equatorial Atlantic. In: Mascle, J., Lohmann, G.P. and Moullade, M., Eds., Proceedings of the Ocean Drilling Program, Scientific Results, 462 p.

[39] Aadjour, M., Slimani, H., Fedan, B., Elzaroug, R.F., Rasul, S., Thusu, B., and Morabet, A. (2005) Palynostratigraphie des dépôtsjurassico-crétacés des sondages MAC-1 (bassin de Doukkala) et ADM-1 (bassind’Essaouira), Ouest du Maroc. Bulletin de l'Institut Scientifique Rabat, Section Sciences de la Terre, 27, 1-15.

[40] Oboh-Ikuenobe, F.E., Obi, C.G. and Jaramillo, C.A. (2005) Lithofacies, Palynofacies and Sequences Tratigraphy of Paleogene strata in Southeastern Nigeria. Journal of African Earth Science, 41, 79-101. http://dx.doi.org/10.1016/j.jafrearsci.2005.02.002

[41] Ola-buraimo, A.O. and Boboye, O.A. (2011) Palynological Investigation of the Albian to Lower Cenomanian Bima Formation, Bornu Basin, Nigeria. World Applied Sciences Journal, 12, 1026-1033.

[42] Moustafa, T.F. and Lashin, G.A. (2012) Aptian-Turonian Palynomorphs From El-Waha-1 Well, Southwestern, Part of The Western Desert, Egypt. Journal of Applied Sciences Research, 8, 1870-1877.

[43] Atta-Peters, D., Agama, C.I., Asiedu, D.K. and Apesegah, E. (2013) Palynology, Palynofacies and Paleoenvironments of Sedimentary Organic Matter from Bonyere-1 Well, Tano Basin, Western Ghana. Internal Letters of Natural Sciences, 5, 27-45. http://dx.doi.org/10.18052/www.scipress.com/ILNS.5.27

[44] Njoh, O.A., Bassey, E.A., Essien, A.J. and Agbor, V.W. (2013) Palynostratigraphy of Early Cretaceous Sedimentary Deposits from the Rio del Rey Basin, S.W. Cameroon. Journal of the Cameroon Academy of Science, 11, 51-61.

[45] Brenner, G.J. (1976) The Spores and Pollen of the Potomac Group of Maryland: Department of Mines, Geology and Water Resources. State of Maryland Bulletin, 27, 1-21.

[46] Herngreen, G.F.W. and Chlonova, A.F. (1981) Cretaceous Microfloral Provinces. Pollen et Spores, 23, 441-557.

[47] Lawal, O. and Moullade, M. (1986) Palynological Biostratigraphy of the Creteceous Sedimentsin the Upper Benue Basin, N.E. Nigeria. Revue de Micropaleontologie, 29, 61-83.

[48] Traverse, A. (1984) Sedimentation of Organic Particles. Cambridge University Press, Cambridge, 544 p.

[49] Bassey, C.E, Eminue, O.O. and Ajonina, H.N. (2013). Stratigraphy and Depositional Environments of the Mamfe Formation and Its Implication on the TectonoSedimentary Evolution of the Ikom-Mamfe Embayment, West Africa. Central European Journal of Geosciences, 5, 394-406.

[50] Nichols, G. (2009) Sedimentology and Stratigraphy. Blackwell Science, Oxford, 355 p.

[51] Miall, A.D. (2000) Principles of Sedimentary Basin Analysis. 3rd and Enlarged Edition, Springer-Verlag, Berlin, 616 p. http://dx.doi.org/10.1007/978-3-662-03999-1

[52] Dunbar, C.O. and Rodgers, J. (1957) Principles of Straigraphy. John Wiley, New York, 356 p.

[53] Bassey, E.E. (2012). Investigation of the Geochemical Signatures and Conditions of the Formation of Metacarbonate Rocks Occurring within the Mamfe Embayment of South-Eastern Nigeria. Earth Sciences Research Journal, 6, 121138. 